\title{
Who Are the Plain Anabaptists? What Are the Plain Anabaptists?
}

\author{
Cory Anderson ${ }^{1}$ \\ OSU Presidential Fellow \\ and Doctoral Candidate in Rural Sociology \\ School of Environment and Natural Resources \\ The Ohio State University
}

\begin{abstract}
:
I define the plain Anabaptists by answering two essential questions: "Who are the plain Anabaptists" and "What are the plain Anabaptists?” In asking "Who are the plain Anabaptists?” I investigate several dimensions of identity. First, I trace the history of seven religious traditions within Anabaptism: the Swiss Brethren/Mennonites, the Low German/Russian Mennonites, the Hutterites, the Amish, the Brethren, the Apostolic Christian Churches, and the Bruderhof. Second, I explore three categories of people in each group — mainline, conservative, and Old Order — describing the last two as "plain.” Third, I explore scales and indices on which plainness is measured, as well as other measures of who the plain Anabaptist people are. In asking "What are the plain Anabaptists?” I define several ways social scientists conceptualize and describe the plain Anabaptists. I organize the sundry definitions and frames under three categories: the plain Anabaptists as a religious group, as an ethnicity, and as a social system.
\end{abstract}

Keywords: Mennonite, Amish, Brethren, Hutterite, Apostolic Christian, Bruderhof, religious traditions, ethnicity, social system 
Journal of Amish and Plain Anabaptist Studies, Volume 1, Issue 1 (April), 2013

\section{Introduction}

The inauguration of a journal about the "plain Anabaptists" lends itself naturally to establishing parameters about these people, thereby defining the topical criteria of journal submissions. The previous article in this inaugural issue addressed, "Where are the plain Anabaptists?” This present article defines and describes the plain Anabaptists by asking two basic questions: who and what are the plain Anabaptists? For now, I omit two additional questions, namely, "How have there come to be plain Anabaptist people?" and "Why do plain Anabaptist people still exist?" Indeed, a sizeable segment of literature already wrestles with these questions. In this article, I address each of these two questions in turn, synthesizing past literature while suggesting new insights and directions for situating the identity of plain Anabaptists.

\section{Who Are the Plain Anabaptist People?}

Plain Anabaptists are foremost a group with a name and a distinctive history. Broadly speaking, the plain Anabaptists are part of the greater Anabaptist movement. The movement originated across Central Europe in the 1520s and created ripples of new movements in the centuries since. While Anabaptism contained much diversity, historical theologians have argued for several beliefs that distinguished this broad movement from both Catholics and Protestants. Anabaptists emphasized faith and rebirth through both inner regeneration and outer discipleship (obedience to Bible commands and prompting of the Spirit). ${ }^{2}$ They believed all people are endowed with a free will, by which they may choose to yield to God's prompting, first in adult baptism, then through a disciplined lifestyle. Both the Bible and the Holy Spirit guide believers to follow Christ's laws. ${ }^{3}$ The Body of Christ exists literally as the Christian community, where commitment is lived out, and through whom the Holy Spirit speaks into members' lives. ${ }^{4}$ Believers assist one another in mutual aid and keep the community pure by disciplining and expelling deviants. Theological truth is not abstract, but expressed in everyday lifestyle decisions and relations with others. Distinctive practices include baptism of adults (not infants), refusal to fight, nonparticipation in governmental offices, and refusal to swear oaths (Klassen 2001; Snyder 1995).

\section{Seven Anabaptist Traditions}

Much diversity inhabits the Anabaptist movement today. This diversity may be foremost understood as belonging to at least one of seven traditions. The first three traditions were established during the Anabaptist movement's first years: the Swiss Brethren / Mennonites, the Dutch / Russian Mennonites, and the Hutterites. The Amish, the Brethren, the Apostolic Christian Churches, and the Bruderhof are post-inaugural 


\section{Who Are the Plain Anabaptists? What Are the Plain Anabaptists? -- Anderson}

resurgences of Anabaptist theology. The social, political, and geographic context of each group during its origins and historical trajectory shaped each tradition uniquely as their Anabaptist creed and practice responded to context-specific shifts and attributes (Huntington 1993). Figure 1 graphically portrays the seven Anabaptist movements beneath which are select plain affiliations. Appendix A lists all contemporary plain Anabaptist affiliations by these seven categories.

Swiss Brethren/Mennonites: In the early 1520s in Switzerland, a current of scholarly theological debate brought about a renunciation of Catholicism and a reformation led by Ulrich Zwingli. However, some of his closest followers were dissatisfied with perceived compromises of Zwingli in accommodating various state positions and maintaining infant baptism. In 1525, the Swiss government formally supported Zwingli's position and in response the dissenters baptized one another as adults. The new Anabaptist (meaning “re-baptizers”) movement quickly spread across much of Germanic Europe despite omnipresent governmental repression including fines, imprisonment, and capital punishment. The faces of Anabaptism were many, often theologically unaligned. The Swiss Anabaptists (or Swiss Brethren) left an enduring North American legacy when beginning in the late 1600s, they immigrated to Pennsylvania upon invitation of William Penn. From there they moved into Virginia, Ontario, and the Midwest, following the frontier as it opened to European settlement (Dyck 1966; Loewen et al. 1996; Snyder 1995).

Russian (Low German) Mennonites: A second, somewhat independent Anabaptist movement arose in Holland. Anabaptist precepts leaked into the country from Strasbourg in the early 1530s. Over a few short years, the new movement grew, but divided into violent and nonviolent strands. Menno Simons, a Catholic priest, joined the nonviolent branch in 1536. He successfully organized the scattered followers and presented a thorough and articulate written defense of beliefs, so that his Anabaptist orientation came to dominate, extending from the Low Countries across Northern Germany and to Danzig, Poland. Though the "Mennonites," as they came to be known, enjoyed around two centuries of economic prosperity and governmental tolerance after an initial wave of repression, some moved to the Ukraine (Russia) beginning in the 1780s on invitation of Catherine the Great, who was seeking German farmers to build up the land (Dyck 1966; Klassen 2009; Snyder 1995). When their exemption from compulsory military service discontinued less than a century later, many began migrating to the American and Canadian Great Plains beginning in 1874. Two world wars, repeated famine, and communism took a severe toll on the remaining Russian-based Mennonite 
Journal of Amish and Plain Anabaptist Studies, Volume 1, Issue 1 (April), 2013

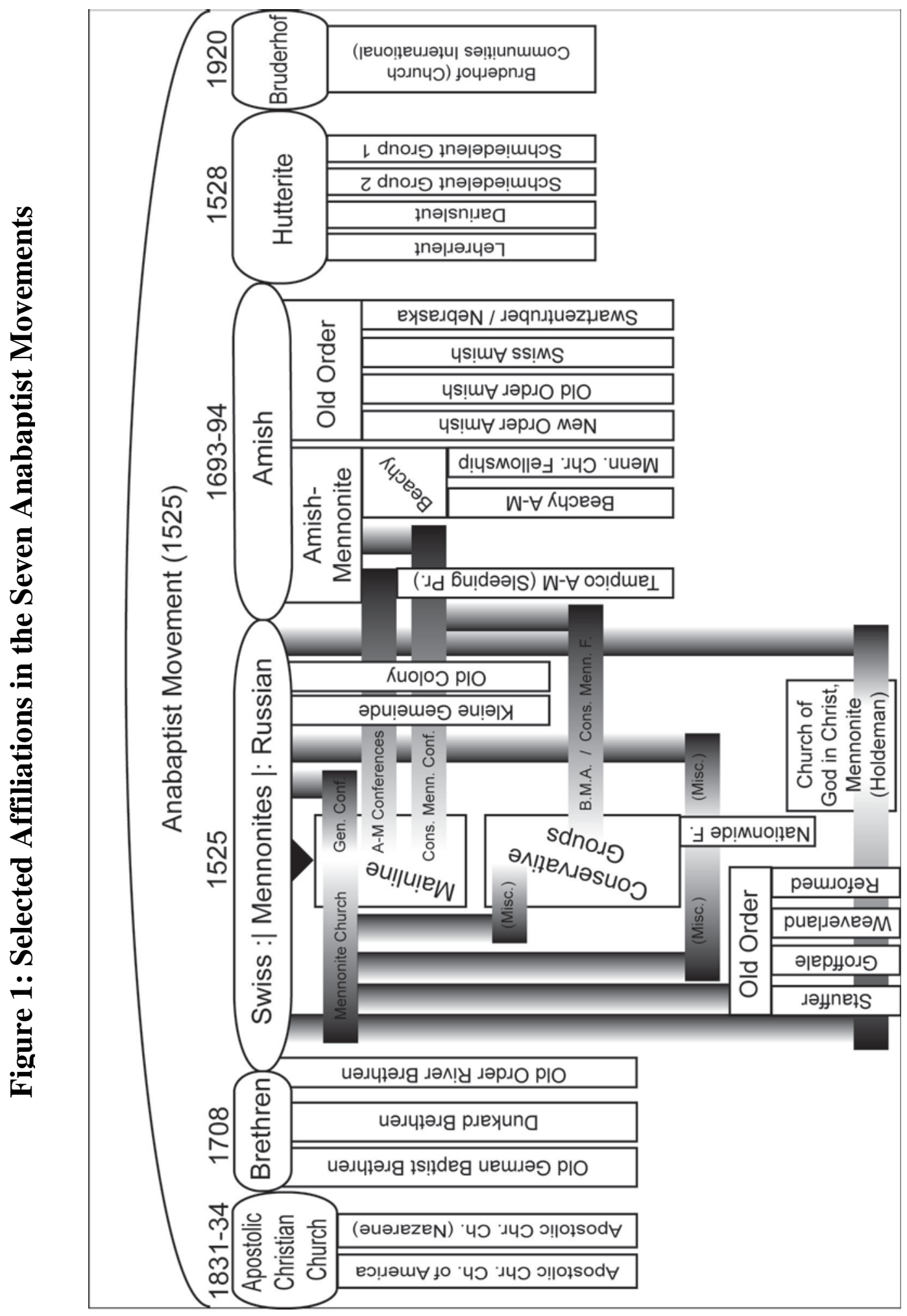




\section{Who Are the Plain Anabaptists? What Are the Plain Anabaptists? -- Anderson}

communities. With the help of American Mennonites, refugees attempted immigration toGermany, western Canada, and South America, though not nearly as many left as sought to. Today, colonies of plain Russian (or “Low German”) Mennonites exist throughout the Americas (Dyck 1966; Loewen 2008).

Hutterites: In 1528, Anabaptists in the Austrian Tyrol and Moravian regions united and, in 1533, many agreed to establish communes as encouraged by leader Jacob Hutter. Moravia became a haven from persecution, and at their peak, these so-called Hutterites had something on the order of 20,000 to 40,000 people living in up to 85 to 90 colonies there. They appealed to a variety of classes and nationalities, which joined the colonies (Gross 1997; Packull 1995). The Thirty Years’ War destroyed many colonies, climaxing in the final 1622 forceful eviction of all Hutterites. They migrated east into Slovakia, Hungary, and Romania/Transylvania, and beginning in 1770, into the Ukraine. Through all this migration and persecution, their practice of community of goods was weakened and largely discontinued for a time. Three movements of communal resurgence arose in Ukraine, and each subsequently migrated to South Dakota in the late nineteenth century, escaping political changes in Russia. During World War I, nearly all Hutterites then moved to Canada to flee American draft pressure. These three ${ }^{5}$ major communal branches persist today across the American and Canadian Great Plains (Bennett 1967; Hostetler 1974; Janzen and Stanton 2010; Peters 1965).

Amish: In the 1670s and 1680s, Ulrich Müller, a convert to the Swiss Brethren, was ordained bishop and became an itinerant preacher, especially in the Swiss Oberländer region where many converted to Anabaptism. This wave of new converts came to clash with the longer-established Swiss Emmentalers. In the summer of 1693, the convert group appointed Bishop Jacob Amman to reason with the Swiss Emmentalers. By then, many of the Swiss Brethren, especially the newer converts, including Ulrich Müller, had relocated to the Alsace region of present day France, including Jacob Amman. Jacob Amman returned to Switzerland, and under risk of apprehension by authorities, spent the remainder of the year negotiating points of communion frequency, relation with those who assist but do not join the Anabaptists, extent of shunning transgressors, and points of separation from society in daily practice. The meetings failed and Amman and accompanying delegates excommunicated six leaders.In March of 1694, the Swiss Emmentalers issued a notice of separation to all who fellowshipped with Amman, thus completing the division (Beachy 2011). Through the 1700s, the Amish settled Pennsylvania and followed the Midwest frontier as far west as Kansas. In the 1860s, the Amish gradually divided into Old Order and conservative (Amish-Mennonite) groups (Nolt 2003; Yoder 1991). These two Amish branches have diversified since (Anderson 2011). 
Brethren: Shortly after the Amish division, another wave of converts emerged in western Germany. These broke from the Calvinist and Lutheran state churches, merging elements of Radical Pietistism and Anabaptism. In 1708, their movement began when adults were baptized in a river and into a new congregation. At this point, the converts rejected the general Pietistic position that an organized church was unnecessary. Known as the (Schwarzenau) Brethren, they associated some with the Swiss Brethren, but felt this latter group lacked inner spirituality. Soon after establishment, the group migrated to the Netherlands and then to Pennsylvania. In the early 1880s, the Brethren experienced a three-way division (Bowman 1995). ${ }^{6}$ The group goes by several names, and Brethren denominations use combinations of these words in their denominational title: brethren, German Baptist, dunker, and/or old/old order.

Apostolic Christian Church: In 1828, the young, university educated Samuel Froehlich was assigned as a minister to a Swiss state church, where his enthusiastic preaching won many devotees. However, because he developed beliefs divergent with the state church, the church dismissed him. In particular, Froehlich came to oppose the state church's use of infant baptism and increasing rationalistic/humanistic bent in theology. In 1832 he took to itinerant preaching, including returning to his first church and baptizing adults there. His travels brought him into contact with Swiss Mennonites, from whom he learned additional Anabaptist beliefs, but also distanced himself from them for a perceived lack of inner spiritualism. Over the next decade, the movement grew quickly. In 1843, Swiss authorities expelled Froehlich from the country, but he continued to be in demand as a preacher. He particularly emphasized greater attention to processes of repentance. Already in the late 1840s, immigration among Apostolic Christians to America was starting and continued through the century. They settled in New York and the Midwest, and their enthusiastic preaching won many converts from the plain sects, particularly the Amish-Mennonites; they thus inherited the nickname "New Amish" (Klopfenstein 2008). In the 1830s, the movement also spread to Hungary and southeastern Europe and took on the name “Apostolic Christian Church (Nazarene).” The two denominations today share associations. ${ }^{7}$

Bruderhof (Church Communities International): After World War I, the German Youth Movement promoted a society without class and war, a movement that Dr. Eberhard Arnold, a respected speaker, and his wife Emmy adopted. They moved to a rural village in Germany in 1920 and established a communal group based on literally practicing New Testament dictates, including the Sermon on the Mount. The settlement attracted many well-to-do professionals across Europe. With the growing dominance of the National Socialist party, the colony completed evacuation to England by 1937. In 1940, the pacifist, part-German commune once more fled, this time to Paraguay, where 


\section{Who Are the Plain Anabaptists? What Are the Plain Anabaptists? -- Anderson}

many Russian Mennonites were also settling to escape war. In the 1950s, communities were established in the U.S. and Britain. The U.S. colonies grew rapidly because of many new converts at mid-century and the acquisition of a successful production company, though the growth was paralleled by accompanying power struggles and purges as they adjusted to place, power, and people (Allain 1992; Mommsen 2004; Mow 1989; Oved 1996; Zablocki 1971). Associations with the Schmiedeleut Hutterites were established thereafter but broken off; today the Bruderhof maintains an independent identity (Janzen 2005). Their German youth movement-based cultural practices, psychological persona, preoccupation with public image, self-sufficient pursuit of professional occupations, political activism, and ambiguous but authoritarian power structure differentiates them (Howlett 2006; Rubin 2000) from the Hutterites to the point where their collectivist organization is one of the only uniquely homophilous features. No plain Anabaptist group has polarized opinion like the Bruderhof, one side applauding their veritable Christian spirituality and community structure, the other referencing cult-like characteristics; among the latter are a couple of 'escape' autobiographies authored in conjunction with Gertrude Enders Huntington.

Limitations: Using historical traditions to define plain Anabaptist groups are limited. While all Amish, Hutterites, Apostolic Christian Churches, and Bruderhof communes are within our parameters, not all Swiss Mennonites, Russian Mennonites, and Brethren are, nor are any other Anabaptist traditions not mentioned here that have no plain counterpart, including the Mennonites remaining in Europe. In addition, traditions have limitations in defining plain groups because it confines the trajectory of each subgroup to its taxonomy. Boundaries appear firm, however, in practice, traditions intersect as they share social and geographic space, and as new movements arise as a product of this intersection. Five examples will suffice.

1. When the Amish divided into two camps in the late 1800s, the progressive AmishMennonites formed three regional conferences, which one-by-one merged with the parallel regional Mennonite conferences (Yoder 1991). Some "Mennonite” groups today have more Amish stock in their heritage than Mennonite. Assessment varies on whether contemporary Amish-Mennonites like the Beachys may be claimed (Anderson 2011; Scott 1996) or rejected (Kraybill 2010) as true “Amish.”

2. The Brethren emphasis on Pietism and baptism by immersion impacted Mennonite theology in southeastern Pennsylvania in the 1700s, giving rise to the River Brethren (Brethren in Christ), a Mennonite group by heritage but with Brethren theology (Brechbill and Dietz 1972). 
Journal of Amish and Plain Anabaptist Studies, Volume 1, Issue 1 (April), 2013

3. The Bruderhof, upon arriving in the United States, established fellowship with the Schmiedeleut Hutterites, melding two traditions, though the tenuous merger later resulted in separation (Janzen 2005; Janzen and Stanton 2010).

4. In the 1980s, the Charity movement emerged with members from Amish and Mennonite ranks. They disdained the traditions and heritage defining Anabaptists groups and implemented a pietistic revival movement that both depended on the heritage of existing Anabaptist traditions while simultaneously denouncing identification with them (Petrovich 2013).

5. The Nationwide Fellowship began in the 1950s as a network emerging from the assimilating bodies of Swiss Mennonites in the U.S., but has come to include many Russian Mennonite churches in Canada.

\section{Variation within Traditions: The Old Order, Conservative, and Mainline Expressions}

A second layer of identifying this journal's subject matter (as well as understanding diversity within the Anabaptist movement) is in distinguishing up to three parallel movements occupying each tradition: the Old Order, conservative, and mainline expressions - the first two being "plain” (Figure 2). Some complications of course exist in delineating three types, as if the world of Anabaptism can be cut cleanly into three camps. Indeed, markers between each set of movements may be abstract and subtle or symbolic and visible. Differences and diversity certainly persist within each type as well.

Difficulties also exist with terminology as well. The "mainline" has been referred to as mainstream, liberal, assimilated, and progressive, terms varying in their tone and assessment. “Conservatives,” rarely referred to at all outside Scott's (1996) foundational work, have been called on at least one occasion "transitional" (Kraybill and Bowman 2001), ${ }^{8}$ as if locked into a short jaunt from Old Order to mainline. "Old Order” is a fairly universal word. As such, defining the Old Order-whether across Anabaptist traditions or within a particular one- -has commanded more attention in research than defining the conservative wing; hence more attention here will be given to fleshing out this movement.

Distinctive Old Order, conservative, and mainline paradigms were evident by the late $19^{\text {th }}$ and early $20^{\text {th }}$ century, when the Swiss Mennonites, Amish, and Brethren divided into three distinct camps. Delineating the Old Order from conservatives is clearest among those groups rooted in the eastern U.S. by the late 1800s (Amish, Swiss Mennonites, and Brethren) when they concurrently encountered Protestant evangelicalism (Kraybill 1987). The Hutterites, Russian Mennonites, and Apostolic Christian Churches have encountered 


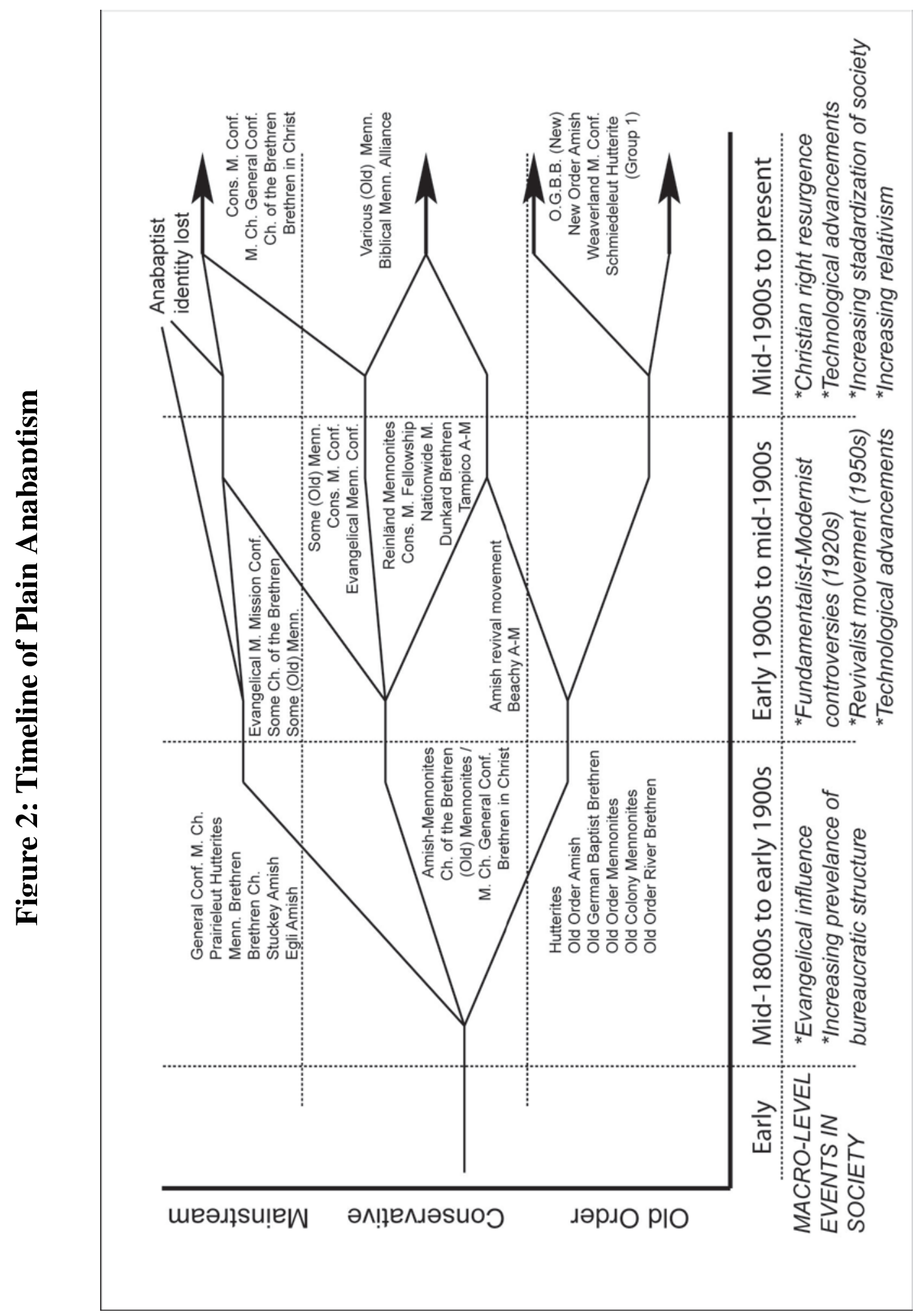




\section{Journal of Amish and Plain Anabaptist Studies, Volume 1, Issue 1 (April), 2013}

Protestant evangelicalism in different places, different eras, and/or different ways. Hence, great difficulty is created in trying to dissect whole elements of evangelical influence both within and across these traditions.

Core shifts among those rejecting the Old Order included the "development of formalized religious and social structures, the emergence of abstract modes of thought, compartmentalization and specialization, and a shift from contextualized, communityoriented authority to codified, legalistic authority” (Hostetler 1992). Often the majority, conservative churches embraced a mixture of Anabaptist and evangelical theology. Mainline groups hastened the transition to evangelicalism, at times with a later loss of Anabaptist identity altogether.

As Scott (1996) observes, Old Orders “questioned following trends and techniques originating from popular modern churches who had no convictions on the cherished doctrines of non-resistance and non-conformity. They saw the introduction of Sunday schools, revival meetings, colleges, organized missions, and English church services as an open door to ... the worldliness of American Protestantism.” Instead, Old Orders sought to remain separate from worldliness—including Christian worldliness—by maintaining the primacy of the religious community, providing members protection from a corrupt, worldly society through a meso-level mediator between society and the individual. The Old Orders emphasize the necessity of yielding one's will to the religious community as evidence of regeneration (Cronk 1981; Hostetler 1992; Hostetler 1996; Oyer 1996). The moral authority of the community, to which individuals yield, is concerned with tangible sacred practices, which spans a broad scope of behavior and contexts (Geiger 1986; Kraybill and Bowman 2001; Olshan 1988) and gives meaning to what is read in the Bible (Enninger and Raith 1982; Rumsey 2010). The community thereby creates strong structural, symbolic, and socialization tools for community perpetuation (Anderson 2012b; Enninger 1988). The term "Old Order” may come from these groups keeping the "old order of service," that is, without Sunday school, Protestant hymns, and other evangelical embellishments, or it may be the rough English translation of "alte Ordnung," where “order/Ordnung” means more than church rules, but is a deeper system and basis of togetherness reflecting God's ordering of the universe (B. 1982).

Conservative identity did not begin to solidify until several decades after these divisions of the 1800s. Through the first half of the twentieth century, evangelical Protestant denominations divided. Modernists embraced rational and scientific thoughtprogressing with societal advancements - while fundamentalism emerged as a fusion of nineteenth century Biblical literalism and other movements that challenged the apparent secularization, modernization, and urbanization of society (Marsden 2006).The conservative Anabaptists defined themselves by fundamentalism. The fundamentalist 


\section{Who Are the Plain Anabaptists? What Are the Plain Anabaptists? -- Anderson}

movement among conservative evangelical Anabaptists differed from the broader Protestant evangelical-fundamentalist movement in their "softening of the constricted language of inspiration and the creedal quality of the 'fundamentals' [which consequently] placed them in an older tradition of theological orthodoxy... [They] thought of themselves as more fundamental than the fundamentalists in that they sought to preserve and even revitalize the historic fundamentals like nonconformity and nonresistance...” (Toews 1983).

Elements of distinctiveness were still present among these fundamentalists, though they had embraced evangelical innovations as well. What appears to define this emerging "conservative" category of Anabaptist is their retention of community-proscribed, highly visible symbolic practices, the essence of which is transmitted across generations. These practices transcend the Biblical literalism of fundamentalists in that they are concrete in expression (rather than abstract) and have no face-value Biblical directive (rather than holding word-for-word Bible texts as the only source of legitimate religious inspiration).

Symbolic distinctives that conservatives have upheld since the turn of the century include an array of practices dropped (or never embraced) by mainline Anabaptists. These include a religious head covering and long hair for women, dresses for women, long pants for men, the non-wearing of jewelry, non-ownership of television and nonattendance at movie theaters, refusal to hold public office or to serve in combatant military positions, separation from consolidated K-12 public schools, ${ }^{9}$ gender-based family and church roles, a cappella congregational singing (non-instrumental) in church

services, rejection of religious icons and paraphernalia, endogenous marriage, ${ }^{10}$ unsalaried ministers chosen from amongst the laity, and the necessity of religious community in the individual's life. While there may be a few exceptions to several points, if a church or individual discontinues any boundary, they are no longer conservative, but mainline. Admittedly, a fuzzy categorical moment in time frames a church or individual during the switch from one category to another, a change that is seldom instantaneous.

As evangelical bodies of Brethren, Mennonites, and Amish-Mennonites morphed into mainline denominations through the twentieth century, factions withdrew to preserve the aforementioned distinctives (and other particulars unique to the movement). Prior to the fundamentalist controversies, the Brethren had divided into Old Order (Old German Baptist Brethren), conservative (German Baptist Brethren), and progressive (Brethren Church) groups in the 1880s, the former defined by emphasis on purity of the church and the latter on salvation of individual souls. The conservatives were unwilling to sacrifice either, and the large majority of Brethren accepted the fragile merger of these two 
Journal of Amish and Plain Anabaptist Studies, Volume 1, Issue 1 (April), 2013

concepts, remaining in the conservative camp. However, within a generation, the majority were adopting evangelical theology and processes, moving towards the mainline. The small Dunkard Brethren faction withdrew and has remained in the conservative camp, while a larger conservative movement was never forthcoming due to the loyalty of members to the denomination. Today, the Church of the Brethren is a denomination with much variation — but all of a mainline nature (Bowman 1995; Fitzkee 1995).

The evangelically-oriented Amish-Mennonites, which had divided with the Old Order Amish in the 1860s, merged with the (Old) Mennonites (of largely Swiss origin) in the early twentieth century. The (Old) Mennonites had also experienced an Old Order withdrawal in the late 1800s. The movement upgraded to grandiose proportions with the growth of the (Old) Mennonite Church General Conference in the early 1900s. From the 1940s through the 1960s, this behemoth-sized (Old) Mennonite/Amish-Mennonite body discontinued the conservative and fundamentalist attributes of their denomination. Numerous regionally-based splinter groups emerged, constituting one of the largest conservative Anabaptist bodies, espousing fundamentalist creeds and theological belief systems (representative of Daniel Kauffman's Doctrines of the Bible [1928]) and individual emphasis on rebirth, yet retaining components of Old Order-style community primacy. This Conservative Mennonite Movement included a second group of congregations from Amish background. In 1910, the Conservative [Amish] Mennonite Conference was established as an evangelically-oriented Amish group. As the conference paralleled the assimilation path of the Mennonites (albeit, about a generation behind, and in a fundamentalist, not a modernist, direction), churches similarly broke away and joined the Conservative Mennonite Movement (Scott 1996).

Conservatives consist not only of Anabaptist churches that withdrew from mainline movements, but also movements away from the Old Order. Indeed, what are today the assimilated bodies of Mennonites and Brethren were more "conservative" than "mainline" immediately after the late 1800s Old Order divisions. Through the twentieth century to the present, movements occasionally emerged from the Old Order and joined the conservative domain, most notably the Beachy Amish-Mennonite/Fellowship movement, which left the Old Order Amish at mid-century and adopted evangelical/revivalist methods and theology (Anderson 2011). Another notable shift from Old Order to conservative in the twentieth century has not been at the group level, but at the individual and household levels. Given the diversity of groups already available, defectors join existing groups like the Beachys or conservative Mennonites rather than start a new movement (Baehr 1942; Hurst and McConnell 2010). 


\section{Who Are the Plain Anabaptists? What Are the Plain Anabaptists? -- Anderson}

Since the 1960s, several other groups have broken partially with Old Order bodies and straddle the line between "Old Order" and "conservative.” The New Order Amish of the 1960s sought to integrate evangelical reforms, but retained salient symbolic markers of Amishness, including the horse and buggy (Kline and Beachy 1998; Waldrep 2008). The Old German Baptist Brethren (New Conference) emerged from their Old Order parent group in 2008. They relaxed a few technological guidelines and adopted evangelical methods (such as supporting international relief agencies) and may very well join conservative ranks in the future given their intense associations with Christian Aid Ministries. The Schmiedeleut Hutterites, already on the progressive fringe of Hutterian society, divided in 1992. "Group 1" has adopted evangelical and missionary practices, as well as engages in greater rationalization of traditional/symbolic practices (Janzen and Stanton 2010).

Several plain Anabaptist bodies lack a distinct Anabaptist tradition, but fit firmly into either the conservative or Old Order camp. Since its establishment in 1982, the Charity movement has appealed to Amish, Old Order Mennonites, conservative Mennonites, and non-Anabaptist seekers. Its constituents embrace an intense and emotional revivalist Pietism and born-againism. They reject community structures at the constituency and congregational level, handing religious authority to families. While clearly antagonistic to Old Orders, their boundaries symbolically fit conservative circles, among whom they circulate socially. During the early years of establishment, several other bodies pulled members from Russian Mennonite, Swiss Mennonite, Amish, Brethren, and/or non-Anabaptist backgrounds, including the Church of God in Christ, Mennonite [Holdeman] (conservative), the Scottsville, Kentucky-based churches (Old Order), and Elmo Stoll's Christian Communities (Old Order).

Further, plain Anabaptists are changing, with no guarantee that any affiliation may be appropriately labeled "plain” in a generation. Change occurs when a plain group alters certain structural mechanisms upon which their distinctiveness rests, triggering a path dependent process of assimilation into the societal mainline. The Prairieleut Hutterites, upon arriving in America, never organized collectivist colonies, opening their structural gates to external influences (Janzen 1999). The Alexanderwohl Mennonites similarly failed to reestablish their distinctive social and economic village system from Russia, causing a structural rupture that also triggered assimilation (Longhofer 1993). Theological revisions to accommodate evangelical theology account for-in part- the assimilation of the Evangelical Mennonite Brethren (Redekop 1989) and the Church of the Brethren (Fitzkee 1995) as well. 
Journal of Amish and Plain Anabaptist Studies, Volume 1, Issue 1 (April), 2013

In summary, the fundamental difference between the Old Order and conservatives is the former's orientation and emphasis on societal inwardness and separation/communal purity and the latter's orientation and emphasis on religious engagement with society, vis-à-vis a Protestant evangelical framework (Knight 1980).

\section{Indices and scales of plainness}

Dichotomous typologies — such as "conservative" and "Old Order"-are critiqued broadly by social scientists. Such critiques are germane, as typologies have shortcomings. The New Order Amish, the Old German Baptist Brethren (New Conference), and Schmiedeleut Hutterites (Group 1) seem a little too "conservative” for Old Orders, but also a little too "Old Order" for conservatives.

Even within the two types, there is tremendous diversity. It can be confusing to those who are only beginning to learn the complex landscape of plain Anabaptist group when the lion's share of the Amish are also known by the moniker “Old Order Amish.” The Holmes-Wayne settlement of northeast Ohio hosts ultra-orthodox Swartzentruber Amish and fairly progressive New Order Amish.Both, however, are in the Old Order camp as defined in this article. The settlement also hosts distinctively plain Wisler Mennonites and Berea Amish-Mennonites but the fringe-plain Biblical Mennonite Alliance as well, all in the conservative camp.

In addition to traditions and typologies, diversity may be understood in terms of scales. Scales are used by both the plain Anabaptists and scholars to conceptualize change and diversity. The Amish refer to "low" and "high" groups, and in a similar vein, scholars have used concentric rings emanating outward to describe the linear nature of assimilation among denominations in Anabaptist settlements (Hostetler 1993; Raith 1980). Beyond these descriptive labeling and ranking exercises, researchers have turned assimilation scales into entire theoretical frameworks. Driedger (1977) refers to a "ladder," upon which he ranks four Anabaptist traditions on structural and symbolic scales, concluding that the middle groups will be least likely to cope with assimilation pressures as isolation decreases. While his conclusions seem more prophetic than deductive, his work significantly establishes variables of an index.

Kraybill (1994) also constructs a scale for the case of four Amish subgroups in Holmes County. He suggests that groups with greater viability reject more technological advancements, measured on six variables. Technology in turn predicts retention of offspring. He further postulates the relationship may be spurious if underlying ideologies and mindsets are the variables predicting both technology and retention. Because retention decreases with acceptance of technology, Kraybill describes the low/high 


\section{Who Are the Plain Anabaptists? What Are the Plain Anabaptists? -- Anderson}

linearity as an "escalator," conveying an image of change that is both automated and unidirectional.

The picture painted by an escalator, though, is of inevitable movement towards assimilation: a machine of upward mobility locks people into a set path. More distinctive groups with a high birth rate feed members to less distinctive groups; those recipient groups in turn feed members to even less distinctive groups. In less uncertain terms, plain Anabaptists share this framework and call it "drift," as in, people floating downstream in a river, powerless to stop the current. These metaphors suggest that (1) individuals lack agency and are victims to social forces beyond control, (2) movement and change is steady and constant, and (3) movement and change is unidirectional.

May I suggest an "elevator” as capturing more closely the linear diversity and change along this continuum? An elevator has the automation and mechanization of social forces captured in an escalator but permits agency found in the use of ladders. With an elevator, actors step on at a given floor and move in conjunction with others in a single direction, but that direction has multiple stops selected by users. Some actors may cross many floors at once while others may move just a few. Further, actors tend to move with others when the mechanized system provides the opportunity to move, rather than each stepping on the ladder or escalator according to random distributions of time. Figure 2 illustrates these epochs of mass movement. What few cannot wait for an elevator (a large-scale social movement) may use the stairs at a greater personal cost; the trip is made alone with greater physical expenditure.

At risk of confusing "high" and "low" concepts, I suggest the top floor is more illustrative of distinctive groups and the bottom floor, the mainline. Movement within and among the quiet top floors is much less, while there is more movement among the middle and lower floors where the bustle of activity usually occurs. Some elevator cart "movements" do not even reach the top floors because most service is performed on the lower floors. Also, elevators move in two directions. Assuming people are born on each floor, on the Anabaptist elevator the carts going down towards the ground floor are more crowded than the ones going up. Nevertheless, there are ones going up, sometimes containing those from non-Anabaptist backgrounds, other times a small social movement returning to greater community authority and primitivism, such as the Eastern Pennsylvania Mennonite division from Lancaster Mennonite Conference (Graybill 1998) or strict divisions off the Old Order Amish (Hostetler 1993; Hurst and McConnell 2010). Finally, while people in the tower are zipping through the elevator shaft at any given time, many more are content to stay on their floor. 
Journal of Amish and Plain Anabaptist Studies, Volume 1, Issue 1 (April), 2013

Elevators, escalators, ladders, drift, and highs \& lows all presume a linear relationship to assimilation, whereas assimilation may have multiple paths and destinations. They also presume that assimilation may be measured through variables, and that variables are consistent in relation to one another. For example, the largeness of women's head coverings correlates with greater rejection of technology. Alone and together, they may symbolically represent how assimilated a group is. However, scales become easily convoluted when two or more variables do not coincide (Nolt and Meyers 2007).

Several examples illustrate this. First, Hurst and McConnell (2010) argue for the inadequacy of a modern/traditional scale in describing Amish diversity in Holmes County. Amish groups differently resolve internal and external social changes, boundary maintenance issues, and the tension between autonomy and collectivity, resulting in multifaceted diversity.

Second, the Eastern Pennsylvania Mennonite Conference has Sunday school, missions, revival meetings, and Bible schools, all evangelical programs their Old Order Weaverland Mennonite Conference (Horning) neighbors do not have (Lee 2000). In this regard, Easterns are more progressive than Hornings. Easterns, however, are on the whole more plainly dressed. They also have a greater sense of community conformity in practices, whereas greater variation exists among Hornings. In this regard, Easterns are more conservative. Such cases suggest linear models have real limits and great potential for creating new stereotypes that gloss over the realities and diversities of plain Anabaptist groups.

A third instance of intra-tradition inconsistency is comparing the Midwest Beachy Amish-Mennonites with many Old Order Amish of large Midwest settlements. While the Old Orders may prohibit ownership of automobiles_-a line the Midwest Beachy churches do not take - the Midwest Beachy churches dress on the whole much plainer than their Old Order counterparts (Anderson 2012a) and have a stronger boundary against digital technology than Amish have accepted-such as the rejection of voice mail and answering machines. In comparing Amish to their conservative Anabaptist neighbors, Knight (1980) adds this:

"Very conservative Old Order communities are often rather tolerant in regard to the consumption of alcoholic beverages, the use of tobacco, and premarital and prebaptismal adolescent activities. Descendant churches, in contrast, maintain highly Puritanical standards for both adult and juvenile behavior. Thus congregations which are 'liberal' in the more usual Protestant sense are extremely conservative in the Amish system, while 


\section{Who Are the Plain Anabaptists? What Are the Plain Anabaptists? -- Anderson}

the more 'conservative' churches are quite liberal in terms of those charactecistics invoked as ethnic markers" (232).

When conducting inter-tradition assessments, each tradition has developed symbolical and structural systems with pertinent meaning and viability in buffeting assimilation forces that serve them for their context. Assessing the level of plainness of Hutterian collectivism against Amish rejection of engine-propelled vehicles distracts from the functionality and symbolism each serves in its context. Pietism fails as an indicator of conservatism when comparing the River Brethren and Charity churches. Each embraces Pietism, but miscellaneous structural variables temper its usefulness as a measure. That said, carefully selected symbolic indicators have been used with much success in cases outside Anabaptism (Waters and Jiménez 2005), but more research would test which Anabaptist indicators are universal and which find usefulness only within traditions.

Steve Nolt twice demonstrates the utility of a two-axis graph to explain the diversity of plain churches. His first study (Nolt 1999a) locates churches in Northern Indiana within a grid. One axis represents "refinement," a value that emerged in the Victorian era as a contrast against rudeness and vulgarity. Refinement was a more deliberate identity construction. Some Anabaptists refined plainness to remove its baseness and uncivilized attributes; it found expression in refined-but-plain clothing, institutional codification, and other social domains. The other axis is technological conservatism. Old Orders rejected the refinement of conservative Anabaptist groups. However, some were more technologically accommodating (Wisler Mennonites, Old German Baptists, Beachy Amish-Mennonites) than others. Among refined Anabaptists, some were very technologically progressive and embraced refinement without plainness (mainline churches) while others were refined but plain and technologically moderates (conservatives).

In the second study, Nolt and Meyers (2007) interpret Amish diversity in Indiana along communal/individual and rational/traditional axes, developing four types: unreflectively and intensely sectarian, self-consciously communal, creatively communal, and "New Order." Dual axes are a relatively untried framework tool from which to explain who plain Anabaptists are. While graphs visually limit the number of variables to two, conceivably, even more nuanced typologies and categories may emerge from multiple scales and variables. Anabaptist churches throughout Indiana could be ranked on all four axes: refinement, technological progressiveness, communal/individual, and rational/traditional. 
Journal of Amish and Plain Anabaptist Studies, Volume 1, Issue 1 (April), 2013

A second limitation to indices and scales is that they rank static variables and consist only of a snapshot. Two groups may be at the same place on technological allowances but are oriented in opposite directions. In North Carolina, both the Yanceyville and Union Grove New Order Amish churches permitted tractors for road transportation in the 1990s. They also prohibited automobile ownership and bicycles. Yanceyville came to permit automobiles, while Union Grove put away tractors for transportation use, allowing bicycles. In technological (tractor) use, the two settlements ranked identically, but one ended up with automobiles and the other bicycles.

This change may be explained in part by Whitehouse (2004), who argues that intergenerational religious transmission reaches a cognitive optimum when the religious protocol and its meaning is easiest to remember, when rituals engender repeatability, reversibility, relative centrality, and appropriate emotional stimulus. When new Anabaptist movements arise, they may borrow elements of another system, but then integrate those elements permanently into their system and "refreeze" their practices. When Amish-Mennonites broke from the Old Order Amish at mid-century, a product of Billy Graham-style evangelicalism, the new churches adopted Sunday school and revival meetings. These two ritual forms lend themselves to spontaneity and unpredictability that potentially opens the new movement to further change as successive generations rework the content of these new religious structures and introduce even newer religious forms. While a segment of Amish-Mennonite churches have progressed in such a manner, others have stabilized the rituals. Sunday school and revival meetings are now as predictable in implicit, informal details as the rest of church services, making its transmission easier than the unpredictability of constant change (Anderson 2011).

A third limitation to scales and indices is that apparent steps towards assimilation may better preserve the community than a group scoring high on traditionalism. Progressivism may also be a sign of stability and continuity. For example, Pennsylvania German among the plain Anabaptists shows signs of convergence with American English, but the product has not been language loss, but bilingual stability, with each language serving a non-overlapping community function (diglossia). Non-sectarian speakers of Pennsylvanian German are largely monolingual, with interference in their English. Because of this bilingual instability, subsequent generations have adopted American English and speak very little Pennsylvania German while language convergence between English and Pennsylvania German among sectarians is indicative of language survival (Enninger and Wandt 1982; Huffines 1989; Louden 1989). Thus, preservation resulted in rapid loss; moderate convergence resulted in stability. 


\section{Who Are the Plain Anabaptists? What Are the Plain Anabaptists? -- Anderson}

\section{In Summary}

I return to the first question of this article, "Who are the plain Anabaptists?" The plain Anabaptists are one of seven traditions that developed out of Anabaptist philosophy. Most traditions have on Old Order, conservative, and mainline expression, the latter not being "plain.” Old Orders and conservatives differ primarily in rejection or acceptance of evangelical Protestant innovations like Sunday school, foreign mission programs, and Bible schools, as well as underlying philosophical preoccupations with born-againism, individual religious devotion, abstract theological debates, and codified religious structures. Both are similar and distinctly plain Anabaptist in their adherence to a consortium of concrete, highly visible symbols that have no verbatim Bible-sourced rationale, yet view these practices as an equally authoritative, generalized cultural embodiment of Biblical literalism. The plain Anabaptists also occupy diverse positions of assimilation into mainline society. This diversity is often understood linearly (such as with the movement of an elevator, carrying people up and down) and measured by symbolic expressions. However, linear models of assimilation based on symbolic indicators fail in that, one, comparing groups on multiple symbolic indicators may produce uneven and contradictory results, two, comparing groups on even one symbolic indicator captures only a static moment and not directionality, and three, comparing two positions on a given practice may seem to be a simple interpretation as to which indicates assimilation more greatly, but the process is not always one of face-value.

In this journal, published articles will primarily pertain to the Old Order and conservative expressions of the aforementioned seven Anabaptist traditions. ${ }^{11}$ Several journals exist that treat mainline Anabaptist issues, including the Mennonite Quarterly Review, The Journal of Mennonite Studies, Brethren Life and Thought, and Brethren in Christ History and Life. Though each has featured occasional articles about the plain Anabaptists, the thrust of The Journal of Amish and Plain Anabaptist Studies is solely on plain groups.

\section{What Are the Plain Anabaptists?}

The above discussion of who the plain Anabaptists are presupposes an agreed-upon definition of "plain.” The word's meaning suggests something drab, absent of ornamentation, simplistic, and unadorned. Applied to people, the word suggests a group whose social patterns, routines, thoughts, and symbols are rudimentary, archaic, unreflexive, common, face-value, and without modern complexity. And yet, plain Anabaptists may build half million dollar houses, patronize coffee shops, operate combines and forklifts, guzzle down Mountain Dew, and wear name-brand clothes (others may eschew all of these). While many Americans quaff nostalgia from the plain 
Journal of Amish and Plain Anabaptist Studies, Volume 1, Issue 1 (April), 2013

Anabaptists’ plainness, recalling a rudimentary, unreflexive era (Trollinger 2012; Weaver-Zercher 2001), the plain Anabaptists themselves are prone to seek simplistic nostalgia, as evident in their attraction to Thomas Kinkaid paintings, quaint folk proverbs, rustic interior decorating such as that of P. Graham Dunn, and novels of far off places and people. These descriptors paint their lives and culture as more complex than "plain” allows. Such inventory suggests the term's inadequacy in describing the array of people who inhabit the classification "plain.” In the absence of a better alternative, I propose continuing its use, but here expanding what the term is intended to package sociologically.

What are the "plain” people? This question moves beyond the exploration of identities, symbols, historic traditions, and lines of assimilation covered in the first section. In answering this question, social scientists have applied miscellaneous theoretical frameworks to the plain Anabaptists, finding explanatory power and areas of lack in each. In reviewing the literature, I propose that the "plain Anabaptists" have three distinct components: they are a religious group, an ethnic group, and a social system. What are the plain Anabaptists? If packaged into one phrase, the plain Anabaptist groups are "ethno-religious societies." The melding of these three dimensions is like a chemical change-inseparable. Disconnecting one societal element clearly from another for study is formidable; they are better understood as interactive, not cohabiting (Nolt 1999b). ${ }^{12}$ With that caveat, to flesh out each concept further, I will analyze the core of each element, exploring what is meant by religion, ethnicity, and social system, occasionally pointing out areas of melding.

\section{Religion}

Descriptions of Anabaptist traditions and identity leave little room for questioning the religious underpinnings of the plain Anabaptists. How, though, does one understand their religion? At least three somewhat related theoretical frameworks are evident in the literature: a religious sect, a social movement, and counterculturalists. ${ }^{13}$ While sect and social movement have some explanatory power, they also forward contradictions to the plain Anabaptist case, contradictions not contained in framing their religion as countercultural. Countercultural comes up short in its lack of theoretical flesh.

Church-sect-cult typologies distinguish between a religion that is, respectively, supportive of the host society's status quo, a faction from the former group in tension with the societal status quo and aiming to restore the religious group to a prior pure state, and an innovative religious movement (Stark and Bainbridge 1979; Troeltsch 1931 [1911]). The plain Anabaptists have been characterized as a sect. On religious grounds, they oppose secular social institutions, intensely practice religious beliefs that distinguish 


\section{Who Are the Plain Anabaptists? What Are the Plain Anabaptists? -- Anderson}

them from societal status quos, and are societal marginals (Hostetler 1993; Mook 1973; Redekop and Hostetler 1977). While this triangular theoretical framework is a magnet for scholarly critiques, it well accents the plain Anabaptists' inherent tension with society because of their religious beliefs and past time orientation.

I do find two significant inadequacies with a sect formulation. Among the plain Anabaptists, sect-like movements calling for a return to "early Christianity” and "early Anabaptism” emerge perennially, accusing parent conservative or Old Order groups of having lost their Christian essence, as if these parents bodies were a status quo "church" (Petrovich 2013; Pride 2003; Waldrep 2008). In this regard, the sect typology insufficiently describes all plain Anabaptists. Are sects of sects becoming like a "church" in their slight shift toward assimilation and destructuralization, or are sects of sects the true "sect" because of their use of past Christian periods in leveling an emphatic religious critique against the present sects, which are themselves a sort of sub-societal "church"? Further, sect typologies suggest that sects slowly transform into a church, spawning new sects in an endless cycle (Stark and Bainbridge 1979). The plain Anabaptists are far from transforming into a church; they have remained distinct for centuries and, even in this modern age, have regularly encountered diverse points of explicit tension with the host society while retaining their identity (Hostetler 1984; Kraybill 2003; Loewen 2008; Place 2003; Wittmer 1971).

Attributes of a (religious) social movement are similar to characterizations of a sect. Both possess an ideological critique of society that rejects the prevailing social order. However, unlike a social movement and a sect, the plain Anabaptists are not actively seeking to revise society. Additionally, existence of social movements and sects are undermined when their objectives are met, while the plain Anabaptists are less responsive to host society reforms (Redekop and Hostetler 1977). As a framework, social movement literature is thorough and precise, and therefore useful in a highly focused study that dissects nuances in schismatic plain Anabaptist movements, as demonstrated in Kniss' (1996) analysis of three plain/mainline conflicts among the Mennonites.

The comparative studies of Foster (1997) and Olshan (1984), which contrast the Amish to, respectively, eastern mystics and Latin American Catholic base communities, flesh out the unique attributes of a plain Anabaptist “countercultural anarchism” (to use Foster's term), which accounts for some inadequacies in sect and social movement frameworks. Classifying plain Anabaptist religion as "counterculturalist” reinforces notions of divergence from contemporary societal norms inherent in these two frameworks. Similarly, “counterculturalist” suggests that their ideology informs multiple cultural domains and practices, including material wealth, violence, arts, technology, and 
Journal of Amish and Plain Anabaptist Studies, Volume 1, Issue 1 (April), 2013

social control (Foster 1997). Because the resulting lifestyle is so fundamentally different, they withdraw from host society cultural and structural patterns to keep their religion pure. While counterculturalists may withdraw from society, sects and social movements do not. They explicitly advocate reforms within the dominant group (Olshan 1984; Redekop and Hostetler 1977), a characterization that better fits some mainline Anabaptist groups (Driedger and Kraybill 1994) and select Anabaptists at the movement's birth (Snyder 1995) than plain Anabaptists today, whose separatism does not have for a goal society’s transformation (Oyer 1996).

Plain Anabaptists felt society was fundamentally flawed and sought a more authentic mode of existence through separation (Foster 1987). The nature of their countercultural religious separatism reflects an end towards alternative existence. They prefer custom and local coordination over law for social and religious control, establish local leadership whose authority is derived from the community rather than extracommunal hierarchies, are inward focused, seek smallness of scale, and emphasize voluntary membership (Foster 1997; Olshan 1984). None of these attributes are inherent in sect and social movement frameworks because their goal is not separatism, but societal reform.

Are plain Anabaptists countercultural, or “countercultural anarchists,” as Foster suggests? The term possesses connotations with beatniks, hippies, Goths, Rastafarians, Hare Krishnas, and other twentieth century youth movements that have relaxed or transformed prevailing social norms and moral orders, especially through artistic expression. "Counterculture” suggests a movement disrespected by mainline society for their offensively dissident cultural claims. Despite living at odds with society like a counterculture, plain Anabaptists are not transforming social norms in a way offensive to the host society, notwithstanding occasional, history- or geography-specific cases (Byers, Crider and Biggers 1999; Erickson 1975). Their practices appear nonthreatening and inoffensive, if not inspiring to some (Trollinger 2012; Weaver-Zercher 2001). Plain Anabaptists, if subversive, are only so indirectly, in that "...they make visible the assumptions of the dominant culture" (Olshan 1984).

In retrospect, then, the plain Anabaptists are an ideological system with supernatural beliefs, that is, they are a religion. Specifically, they are an inoffensive separatist religion that makes no explicit attempt at reforming the host society or dominant religions, yet neither bars converts from the host society nor suppresses implicit critiques of the host that emanate from the plain Anabaptist's very existence. No theoretical framework captures the religious component of the Anabaptists perfectly, though all make a contribution to our understanding, if not by what they correctly predict, than by noticeable divergences. 


\section{Who Are the Plain Anabaptists? What Are the Plain Anabaptists? -- Anderson}

\section{Ethnicity}

The plain Anabaptists may be understood as an ethnic group in that they share common values and behavioral patterns, maintain systems of symbolic and (sometimes) linguistic identification, erect boundaries between their in-group and outsiders, similarly stereotype non-members, direct primary social and psychological ties inward, and possess a shared sense of history, heritage, interrelatedness, and peoplehood (Enninger 1986; Gordon 1964; Nolt and Meyers 2007; Pratt 2004; Redekop and Hostetler 1977). Ethnicity, though a fuzzy and contested concept, fits the plain Anabaptists well. The strength of this ethnic identity delineates them from largely assimilated, mainline Anabaptists, for whom ethnicity is less clear (Nolt 1999b).

Ethnicity is a separate, but interrelated concept, with religion. In Belize, the Mennonite ethnic identity is pronounced enough that the state census includes "Mennonite” as a people group category. Yet, because some non-ethnic Mennonites have joined the Mennonite religion, the census distinguishes between "ethnic Mennonite” and “religious Mennonite” (Roessingh 2007; Van Kampen 2009). In southeastern Pennsylvania, all of the people from the German-Swiss region of Europe were referred to as the "Pennsylvania Dutch," which included plain Anabaptist sects, but also Moravians, Lutherans, and Reformed. As the non-Anabaptist Pennsylvania Dutch assimilated into America through the twentieth century, they simultaneously lost much of their ethnicity (Huffines 1986). Only the plain Anabaptists retained a distinctive Pennsylvania Dutch ethnicity, to the extent where "Pennsylvania Dutch" has been widely confused as synonymous with plain Anabaptism (Weaver-Zercher 2001).

Each major Anabaptist tradition represents a distinctive ethnicity. In one sense, they all have mainland European Germanic heritage, yet they have shaped and evolved elements of this regional culture into a distinctive expression of peoplehood. For example, each plain Anabaptist ethnicity retains elements of Germanic style clothes, albeit varying based on European locality (Bates 2008; Hostetler 1956). These styles have evolved in the interval years so that while they insinuate some resemblance to the old world era, they are now distinctive identity markers of a cohesive ethnic group (Enninger 1980; Janzen and Stanton 2010; Scott 1997; Weiser 1998). Women’s head coverings, for example, have diverse minor modifications - variations on a themeamong subgroups within a tradition, but all are of the same historical species. Hutterite, Swiss-German Mennonite, and Russian Mennonite women's coverings are of different genus (Anderson 2010). ${ }^{14}$ While each group of coverings traces their origin to a European region, the styles have shifted slightly so that identity is no longer tied to that region. As another example, among those plain Anabaptists who still retain an oral German dialect, 
Journal of Amish and Plain Anabaptist Studies, Volume 1, Issue 1 (April), 2013

the language has evolved so that it is now at variance with the mother tongue of their homeland. Their evolved and now unique language is a marker of ethnic identity (Huffines 1986; Johnson-Weiner 1998; Wandt 1988).

Inasmuch as the plain Anabaptists represent ethnicity, they qualify for two subcategories of ethnicity: minority group and transnational group status. Minority status implies ethnic marginalization by the host society because of numeric inferiority and distinctiveness from the dominant people group. Minorities may relinquish this status if they shed unique traits, but instead they typically press for recognition and equality with other ethnic groups. While the plain Anabaptists number far less than the members of any given host society, they are rarely subjected to marginalization, except that which they impose on themselves through voluntary separation (Redekop and Hostetler 1977). For all their peculiarities, in the modern era they have typically functioned quite well socially and economically with their host society, wherever they may be, in comparison to the European epoch of Anabaptist history.

As ethnic groups, plain Anabaptists are better subcategorized as a transnational people than strictly as a minority people. Being a minority group implies more of an attachment or affinity to a geographic place despite marginalization in that place, whereas transnationalism suggests perpetual minority existence for lack of geographic rootedness. The plain Anabaptists are such a migratory people without a homeland (Good Gingrich and Preibisch 2010; Lamme 2001). Even in regions where their presence is long established, where their ethnic imprint is evident on the cultural landscape (Kent and Neugebauer 1990; Noble 1986; Sawatzky 2005; Scott 2001), their apparent willingness to move to emigrate to escape undesirable social changes evidences their lack of a country or region of origin (Anderson and Donnermeyer 2013; Donnermeyer and Cooksey 2010; Loewen 2008; Testa 1992). Under the right conditions, America may trigger the plain Anabaptists' transnational impulse, emigrating en masse and leaving behind only those who will soon assimilate, as happened to the Amish in Europe and the Mennonites in twentieth century Russia. Yet, the modern rootedness of plain Anabaptists in America and Canada, their overwhelming and disproportionate dominance in North America against other countries in the world, does create some complications with them being fully transnational, albeit conservative Anabaptist churches are growing rapidly through Latin America and eastern and southern Africa.

\section{Social System}

Many ethnic immigrants to America have assimilated over the course of several generations, relinquishing their ethnic identity and defining traits. Plain Anabaptist ethnicity is one of few ethnic identities that has remained stable across multiple 


\section{Who Are the Plain Anabaptists? What Are the Plain Anabaptists? -- Anderson}

generations (though not without periodic defections to mainstream America). While some mechanisms of survival are embedded in their unique religious emphases — such as in literal separation from the world-and distinctive ethnicity, others are wrapped up in their social system.

The social system is partially a product of their religion. The plain Anabaptists have created goals based on religious beliefs, and these goals validate the institutionalized means of achieving those goals (Loomis 1960). This institution is, broadly speaking, their social system. Researchers seeking to describe the essence of their social system in a single phrase have used "redemptive community," underpinning first the social system's religious basis and second the local nature of these systems (Cronk 1981; Hostetler 1996; Kraybill 2004). Macro-level forms of plain society exist at the ethnic and religious level more than the social system.

The redemptive community structures a brotherhood permeated with the nature of Christ. Yieldedness to God and the redemptive community is imparted to members, reinforcing the social system, which reinforces in turn members' spirit of yieldedness (Cronk 1981; Hostetler 1993; Kraybill 2004). The redemptive community provides a buffer between the individual—who is prone to collective influence-and competing social systems that vie for individual allegiance (Anderson 2012b; Nisbet 2010 [1953]). The plain Anabaptists view their social system as in conflict with external social systems, with which it attempts to limit linkage (Loomis and Jantzen 1962).

The redemptive community contains a variety of specific social mechanisms (Bennett 1977; Hostetler 1996; O'Neil 1997), which vary with tradition (Kraybill and Bowman 2001). They are many and of varying importance, and scholarly attempts to document them are sincere, but often cherry-picked. For the sake of example, here I will cite several social system processes that, one, constitute and reinforce a redemptive community, and two, flesh out the social system component of what plain Anabaptists are. Their social system includes ceremonial events like rites and rituals (Cronk 1981; Enninger and Raith 1982; Scott 1988), rewards and sanctions on social action (Hamilton and Hawley 1999; Hostetler 1964; Loomis 1960; Stoltzfus 1977), informal boundary maintenance behaviors (Huntington 1984), domains of socialization like family (Huntington 1981; Smucker 1988) and school (Enninger 1987; Hostetler and Huntington 1992; Redekop and Hostetler 1964), control over technology and/or sources of external information (Longhofer 1993; O'Neil 1997; Scott and Pellman 1999), and nuanced economic structures (Dana 2007; Hawley 1995; Longhofer 1993). Some systemic elements serve both a community and a religious or ethnic function. For example, while clothing is a marker of ethnic and religious identity, as discussed previously, clothing 
Journal of Amish and Plain Anabaptist Studies, Volume 1, Issue 1 (April), 2013

also functions to assign and communicate privileges and roles among members (Enninger 1982).

Other social system frameworks suggested for understanding plain Anabaptists have remained obscure, contested, or limited in explanatory power. The preeminent Amish scholar of the twentieth century, John Hostetler, more than any other scholar has grappled with frames defining what plain Anabaptists are. In Amish Society (1993), he makes three systemically related proposals. ${ }^{15}$ First, he defines "commonwealth" as people having "a sense of productivity and accountability in a province where 'the general welfare' is accepted as a day-to-day reality” (5). Of significance, plain Anabaptists lack a "province," the political foundation underlying this framework. The "commonwealth" has received the least attention and is the least defined, least sociological or anthropological, and most usurped by the "redemptive community" framework.

The "high context culture" (Hall 1976) emphasizes people’s involvement with one another and the protection this affords from information overload. In contrast is a "low context culture,” which elevates literacy, logic, rationality, and institutionalization. Overstructuring societies in such formalistic ways alienates individuals from one another, fragments informal social structures, and breeds manipulation through codified processes. Related is the Gemeinschaft typology, which emphasizes kinship, neighborhood, and friendship (Redekop and Hostetler 1977). In both, the social system is comprised of informal connections. Yet, these are somewhat abstract, idealistic types of social systems, not concepts with theoretical rigor, variables, and predictions. Communities may have intense elements of both high and low context, Gemeinschaft and Gesellschaft. They are borderline nostalgic. Their empirical usefulness in expounding in detail has either not been demonstrated or is simply not there. The lack of engagement with the high/low context culture framework beyond Hostetler testifies, perhaps, to its ambiguity.

The most talked-about of Hostetler's theoretical frameworks is the "folk society" (Redfield 1947). He highlighted from this typology Amish characteristics of distinctiveness, smallness of scale, homogeneity, and self-sufficiency from which oral communication and conventionalized ways integrate all of life. He emphasized that tradition sustains the community. Hostetler's use of "folk society" to describe the Amish social system was criticized for three assumptions. First, technology, quaint clothing, and other apparent elements of folk culture were not in themselves a measure of folk society. Second, and related, opponents argued that the Amish were not unreflexive adherents to traditionalism. Through individual agency, some leave, some deviate within the social system, and some choose to stay. Those who stay rationally calculate their decisions to achieve a desired end, which may include technological or fashion restraint. Third, opponents argued against the structuralist view that tradition alone sustained the cohesion 


\section{Who Are the Plain Anabaptists? What Are the Plain Anabaptists? -- Anderson}

of individuals. Rather, individuals may collectively construct tradition as a symbolic culture (not a societal location) (Bronner 2004; Olshan 1981). While such critiques are valid, they may in turn overstate Amish individualistic rationality. The plain Anabaptists' social system may be more aligned with bounded rationality, which recognizes agents' rational choice is limited by context, cultural systems, information gaps, and a constellation of minutiae decision-making irrationalities (Brock 2010). These complexities are inherent to (if not the hallmark of) high context culture, Gemeinschaft, and folk societies, but bounded rationality incorporates the critiques of methodological individualism. The systemic functions of plain Anabaptist society are, then, both a product of social limitations and latent human behavior as well as intentional, rational construction within those limits.

Further, scholars of the Hutterites and Russian Mennonites in particular conceptualize these plain Anabaptists as a European-style village. Structures are arranged around a commons area and include dwelling units, businesses, and buildings used for specialty services and community functions. Surrounding the village are fields where farming is conducted. Trades were operated on a guild system, where specialists oversee the work; division of labor is gendered. Village governance power is distinctive from religious leadership. Households are subject to the community through conditions of land control, production rights, and technological access (Bennett 1976; Hostetler 1974; Longhofer 1993). While the European-style village framework of the plain Anabaptist social system is confined more to Hutterites, Russian Mennonites, and Bruderhof communes than the other groups, its strength is highlighting a social system that accommodates more than one religion, as with the Russian Mennonite colonies of Belize (Plasil and Roessingh 2009), whereas up until now the assumption was one social system per religious group.

\section{Summary and Discussion}

In terms of the "who," the plain Anabaptists belong to one of seven historical traditions, and within each of those traditions, those which are "plain” embrace a conceptualization of their community as "Old Order" (marked by inwardness and separation) or "conservative” (marked by outward evangelical orientations but nevertheless retaining some highly visible markers of separatism). Within both the Old Order and conservative movements, diversity persists, and this diversity may be conceptualized as an elevator in a tall building, where people change floors in either direction; some move together as an act of a social movement, others move individually on the stairs as an act of agency. However useful to understanding diversity, linear scales of assimilation have limitations. First, variables that measure assimilation may be 
Journal of Amish and Plain Anabaptist Studies, Volume 1, Issue 1 (April), 2013

unaligned with one another; multidimensional scales may better interpret diversity than a one-dimensional scale. Second, variables on the scale and static and do not represent directionality. Third, variables may misrepresent actual assimilation; what may appear more progressive may better preserve the community from assimilation than less progressive stances.

In answer to "what," the plain Anabaptists embody three human dimensions: they are a religion, an ethnicity, and a social system. The plain Anabaptists are thus an ethnoreligious society. Each of these domains has been further theorized, but unevenly and somewhat inconclusively. In describing the plain Anabaptists as a religion, they are a break-away separatist group attempting reform, fitting therefore to a sect and social movement, but unfitting to these theories plain Anabaptists are not attempting to reform the host body, nor are they particularly responsive to host body reforms that align with their creed. While their separatism may be more akin to counterculturalists, who seek a more authentic mode of existence, they do not prompt the general disdain from the host society with which counterculturalists are acquainted. Thus, no religious theory appears to fit the plain Anabaptists yet aside from religion in general-having belief in the supernatural. Plain Anabaptists fit the concept of ethnicity well in that they embody a symbolic, historical, and empathetic shared sense of we-ness. If they are also ethnic minorities, they are by intention, not imposition, and if they are a transnational group, they are in their lack of homeland and history of migration. The social system consists of community level functions that bind the members together organizationally. The social system is a redemptive community, in that its social organization serves their religiosity unto an eternal end. The social system is neither erected unthinkingly like a folk society, nor is it maintained solely through agency and rational choice, but is a mixture of both. The system is maintained through bounded rationality, where rationalism exists but is tempered by latent social behaviors and seemingly irrational cultures and contexts.

This paper calls for several directions in answering the question, "Who are the plain Anabaptists?" and "What are the plain Anabaptists?” Descriptive work on plain Anabaptist diversity is endless in itself. In making sense of present, past, and future diversity, I have proposed one theoretical framework, a tower elevator metaphor, which I offer to readers for empirical testing and refinement. I have also suggested the possibility of a multi-linear system to organize plain diversity, a system that may find realization in quantitative inquiry that measures symbolic variables.

Much work remains to be done on applying theory to the plain Anabaptists. Theories of religion have been insufficiently applied to the plain Anabaptist case; meanwhile, sociology of religion has in recent years offered many new testable theories. We stand not only to understand plain Anabaptists better by applying these theories, but 


\section{Who Are the Plain Anabaptists? What Are the Plain Anabaptists? -- Anderson}

also use the plain Anabaptist case to critique them. These groups would certainly provide an edge on empirical testing over mainline groups that do not reveal the modern assumptions built into the theories. In conceptualizing plain Anabaptist social systems, further work could be done in applying bounded rationality to the plain Anabaptist case. But whatever the domain — religion, ethnicity, or the social system — the plain Anabaptists have been under-theorized, victim to an abundance of descriptive studies and interpretive conjectures about plain Anabaptist survival. In this issue, Seonhee Jeong illustrates the utility of the Amish case to refining social capital. The theoretical implications of the plain Anabaptists are many; we stand to benefit much by better connecting our subdiscipline to the other social science disciplines and subdisciplines. 
Journal of Amish and Plain Anabaptist Studies, Volume 1, Issue 1 (April), 2013

\section{Endnotes}

${ }^{1}$ Contact information: Cory Anderson, School of Environment and Natural Resources, The Ohio State University, Room 406A, Kottman Hall, 2021 Coffey Road, Columbus, Ohio 43210. cory@beachyam.org; 3308971426.

${ }^{2}$ While Lutherans advocated salvation by confession of belief alone and Calvinists salvation only for the preordained elect, Anabaptists believed that salvation is by grace, but only to those who have faith in God and do that which God commands.

${ }^{3}$ As opposed to strict Biblicists, who hold only that which comes from the Bible is inspired.

${ }^{4}$ Anabaptists believed the church is necessary to Christian life, but that the church is an assembly of believers without stratification; all have access to God, but access as a church. This was different from Lutherans, which believed the church is not necessary for Christian life, and Catholics, which believed access to God was only through the church. See, for example, the illustration from Raith (1980), page 139.

${ }^{5}$ The Schmiedeleuts now consists of two groups, making the actual number four. ${ }^{6}$ Bowman's Brethren Society is a thorough history of the $19^{\text {th }}$ and $20^{\text {th }}$ centuries, but a detailed comprehensive history of the Brethren's European origins is still wanting.

${ }^{7}$ In late 2012, a nationwide division appeared to be occurring within the Apostolic Christian Church. Minorities advocating positions in greater alignment with past practices and doctrines were withdrawing from churches across the country, though a handful of congregations went entirely with the new movement. The new group is the "Apostolic Christian Faith.”

${ }^{8}$ Kraybill appears to have abandoned this term in recent work (2010), coalescing conservative and Old Order as "traditional groups" as in contrast to "assimilated groups."

${ }^{9}$ Old Order groups are more accommodating to public schooling, especially the Old German Baptist Brethren and the Old Order Amish of some large Midwestern settlements. All but the most progressive Hutterites use a public school teacher and curriculum, but school takes place on the colony with a student body of all Hutterites.

${ }^{10}$ That is, endogamous marriage within conservative- and occasionally to Old Ordercircles. Marriage to non-plain Anabaptists is prohibited. Spouses, no matter what their previous affiliation, are expected to become members at the same church. 


\section{Who Are the Plain Anabaptists? What Are the Plain Anabaptists? -- Anderson}

\footnotetext{
${ }^{11}$ It is possible other plain traditions with Anabaptists heritage or influence exist around the world, given the centuries of upheaval and migration experienced. Articles about these groups are welcome as well.
}

${ }^{12}$ Many plain Anabaptists have similarly erred in dichotomizing "doctrine" (that which is verbatim spelled out in the Bible-like "religion") and "application" (the practice of the doctrine, which is not literally spelled out-like "ethnicity” and "society”), a theological framework borrowed from evangelical Protestantism. It suggests the highest form of religion exists in a vacuum above human experience, whereas the historic thrust of Anabaptism has been the reality of religion through human experience.

${ }^{13}$ The oft-discussed concept of the plain Anabaptists as a "redemptive community" may be considered a religious attribute in some ways, but here is discussed later under social system.

${ }^{14} \mathrm{~A}$ notable exception to covering styles is the sudden popularity of generic or fancy cloth styles, which represent a sudden and perplexing shift in ethnoreligious identity.

${ }^{15}$ That is, three in addition to the Amish as a sect and the Amish view of themselves. 
Journal of Amish and Plain Anabaptist Studies, Volume 1, Issue 1 (April), 2013

\section{References}

Allain, Roger. 1992. The Community That Failed. San Francisco: The Peregrine Foundation.

Anderson, Cory. 2010. The Ornament of a Spirit: Exploring the Reasons Covering Styles Change. Lyndonville, NY: Ridgeway Publishers.

Anderson, Cory. 2011. "Retracing the Blurred Boundaries of the Twentieth-Century 'Amish-Mennonite' Identity." Mennonite Quarterly Review 85(3):361-412.

Anderson, Cory. 2012a. "Midwest Beachy Amish-Mennonite." in Global Anabaptist Mennonite Encyclopedia Online, edited by Sam Steiner. Waterloo, ON: Global Anabaptist Mennonite Encyclopedia Online (GAMEO).

Anderson, Cory. 2012b. "Why Have the Amish Survived?" in Annual Conference of the Society for the Scientific Study of Religion and the Religious Research Association. Phoenix, AZ.

Anderson, Cory, and Joseph Donnermeyer. 2013. "Where Are the Plain Anabaptists?" Journal of Amish and Plain Anabaptist Studies 1(1).

B., J. F. 1982. "Ordnung." Mennonite Quarterly Review 56:382-84.

Baehr, Karl. 1942. "Secularization among the Mennonites of Elkhart County, Indiana." Mennonite Quarterly Review 16(3):131-61.

Bates, Mary Ann Miller. 2008. "Insubordinate Anabaptists in Virtuous Clothing? Amish Anabaptist Subjects in the Context of Bernese Sumptuary and Moral Mandates." Mennonite Quarterly Review 82(4):517-32.

Beachy, Leroy. 2011. Unser Leit... The Story of the Amish. Millersburg, OH: Goodly Heritage Books.

Bennett, Edward M. 1976. "Frames of Reference for the Study of Hutterian Society." International Review of Modern Sociology 6(Spring):23-39.

Bennett, John C. 1967. Hutterian Brethren: The Agricultural Economy and Social Organization of a Communal People. Stanford, CA: Stanford University Press.

Bennett, John W. 1977. "Social Theory and the Social Order of the Hutterian Community." Mennonite Quarterly Review 51(4):292-307. 


\section{Who Are the Plain Anabaptists? What Are the Plain Anabaptists? -- Anderson}

Bowman, Carl F. 1995. Brethren Society: The Cultural Transformation of a 'Peculiar People'. Baltimore: Johns Hopkins University Press.

Brechbill, Laban, and Myron Dietz. 1972. History of the Old Order River Brethren: Brechbill \& Strickler.

Brock, Caroline. 2010. An Integrated Household Economics Approach to DecisionMaking: Dairy System Choice among Organic, Amish, Graziers, and Conventional Farmers in Wisconsin. Doctoral dissertation in Environment and Resources. Madison, WI: University of Wisconsin-Madison.

Bronner, Simon J. 2004. "Plain Folk and Folk Society: John A. Hostetler's Legacy of the Little Community." Pp. 56-97 in Writing the Amish: The Worlds of John A. Hostetler, edited by David L Weaver-Zercher. University Park, PA: Pennsylvania State University Press.

Byers, Bryan D., Benjamin W. Crider, and Gregory K. Biggers. 1999. "Bias Crime Motivation: A Study of Hate Crime Offender Neutralization Techniques Used against the Amish." Journal of Contemporary Criminal Justice 15(1):78-96.

Cronk, Sandra. 1981. "Gelassenheit: The Rites of the Redemptive Process in Old Order Amish and Old Order Mennonite Communities." Mennonite Quarterly Review 55(1):5-44.

Dana, Leo Paul. 2007. "A Humility-Based Enterprising Community: The Amish People in Lancaster County." Journal of Enterprising Communities: People and Places in the Global Economy 1(2):142-54.

Donnermeyer, Joseph F., and Elizabeth C. Cooksey. 2010. "On the Recent Growth of New Amish Settlements." Mennonite Quarterly Review 84(2):181-206.

Driedger, Leo. 1977. "The Anabaptist Identification Ladder: Plain-Urbane Continuity in Diversity." Mennonite Quarterly Review 51(4):278-91.

Driedger, Leo, and Donald Kraybill. 1994. Mennonite Peacemaking: From Quietism to Activism. Scottdale, PA: Herald Press.

Dyck, Cornelius J. 1966. An Introduction to Mennonite History. Scottdale, PA: Herald Press.

Enninger, Werner. 1980. "Nonverbal Performatives: The Function of a Grooming and Garment Grammar in the Organization of Nonverbal Role-Taking and Role- 
Journal of Amish and Plain Anabaptist Studies, Volume 1, Issue 1 (April), 2013

Making in One Specific Trilingual Social Isolate." Pp. 25-65 in Understanding Bilingualism, edited by Werner Hüllen. Frankfurt, Germany: Peter Lang.

Enninger, Werner. 1982. "The Semiotic Structure of Amish Folk Costume: Its Function in the Organization of Face-to-Face Interaction." Pp. 86-123 in Multimedia Communication I, edited by Ernest and E.W.B. Hess-Lüttich. Tubingen: Gunter Narr.

Enninger, Werner. 1986. "The Theme of Ethnicity in the Literature of the Old Order Amish." Pp. 115-36 in Studies on the Languages and the Verbal Behavior of the Pennsylvania Germans I, edited by Werner Enninger. Stuttgart: Franz Steiner Verlag Wiesbaden GMBH.

Enninger, Werner. 1987. "On the Organization of Sign-Processes in an Old Order Amish (OOA) Parochial School." Research on Language and Social Interaction 21:14370.

Enninger, Werner. 1988. "Coping with Modernity: Instrumentally and Symbolically, with a Glimpse at the Old Order Amish." Brethren Life and Thought 33(Summer):15470 .

Enninger, Werner, and Joachim Raith. 1982. An Ethnography-of-Communication Approach to Ceremonial Situations. A Study on Communication in Institutionalized Social Contexts: The Old Order Amish Church Service. Wiesbaden: Franz Steiner Verlag.

Enninger, Werner, and Karl-Heinz Wandt. 1982. "Pennsylvania German in the Context of an Old Order Amish Settlement: The Structural Instability of a Functionally Stable Variety." Yearbook of German-American Studies 1982 17:123-43.

Erickson, Donald A. 1975. "The Persecution of LeRoy Garber." Pp. 84-92 in Compulsory Education and the Amish, edited by Albert Keim. Boston: Beacon Press.

Fitzkee, Donald R. 1995. Moving Toward the Mainstream: 20th Century Change among the Brethren of Eastern Pennsylvania. Intercourse, PA: Good Books.

Foster, Thomas W. 1987. "The Taoists and the Amish: Kindred Expressions of Ecoanarchism." Ecologist 17:9-14.

Foster, Thomas W. 1997. "American Culture through Amish Eyes: Perspectives of an Anarchist Protest Movement." Social Thought \& Research 20(1-2):89-108. 


\section{Who Are the Plain Anabaptists? What Are the Plain Anabaptists? -- Anderson}

Geiger, Annamaria. 1986. "Communication in American Contexts of Religion: Old Order Amish vs. Born-Agains." Pp. 148-69 in Internal and External Perspectives on Amish and Mennonite Life 2, edited by Werner Enninger, Joachim Raith, and Karl-Heinz Wandt. Essen, West Germany: Unipress.

Good Gingrich, Luann, and Kerry Preibisch. 2010. "Migration as Preservation and Loss: The Paradox of Transnational Living for Low German Mennonite Women." Journal of Ethnic \& Migration Studies 36(9):1499-518.

Gordon, Milton M. 1964. Assimilation in American Life: The Role of Race, Religion, and National Origins. New York: Oxford University Press.

Graybill, Beth. 1998. "Mennonite Women and Their Bishops in the Founding of the Eastern Pennsylvania Mennonite Church." Mennonite Quarterly Review 72:25173.

Gross, Leonard. 1997. The Golden Years of the Hutterites. Scottdale, PA: Herald Press.

Hall, Edward T. 1976. Beyond Culture. New York: Double Day.

Hamilton, Jean A., and Jana M. Hawley. 1999. "Sacred Dress, Public Worlds: Amish and Mormon Experience and Commitment." Pp. 31-51 in Religion, Dress, and the Body, edited by Gabriella Lazaridis and Linda B. Arthur. New York: Berg Publishing, Inc.

Hawley, Jana M. 1995. "Maintaining Business while Maintaining Boundaries: An Amish Woman's Entrepreneurial Experience." Entrepreneurship, Innovation, and Change 4(4):315-28.

Hostetler, Beulah Stauffer. 1992. "The Formation of the Old Orders." Mennonite Quarterly Review 66(1):5-25.

Hostetler, John A. 1964. "Persistence and Change Patterns in Amish Society." Ethnology 3(2):185-98.

Hostetler, John A. 1956. "Amish Costume: Its European Origins." American-German Review (Aug-Sept.):11-14.

Hostetler, John A. 1974. Hutterite Society. Baltimore: Johns Hopkins University Press.

Hostetler, John A. 1984. "The Amish and the Law: A Religious Minority and Its Legal Encounters." Washington and Lee Law Review 41(1):33-47. 
Journal of Amish and Plain Anabaptist Studies, Volume 1, Issue 1 (April), 2013

Hostetler, John A. 1993. Amish Society. Baltimore: Johns Hopkins University Press.

Hostetler, John A. 1996. "The Amish as a Redemptive Community." Pp. 346-55 in The Amish: Origin and Characteristics, 1693-1993, edited by Lydie Hege and Christoph Wiebe. Ingersheim: Association Française d'Histoire AnabaptisteMennonite.

Hostetler, John A, and Gertrude Enders Huntington. 1992. Amish Children: Education in the Family, School, and Community. Fort Worth, TX: Harcourt Brace Jovanovich College Publishers.

Howlett, David J. 2006. "The Bruderhof's Systems of Objects': A Case Study in Material Culture and Christian Praxis, 1920-2001." Communal Societies: 19-41.

Huffines, Marion Lois. 1986. "Strategies of Language Maintenance and Ethnic Marking among the Pennsylvanian Germans." Language Sciences 8(1):1-17.

Huffines, Marion Lois. 1989. "Convergence and Language Death: The Case of Pennsylvania German." Pp. 17-28 in Studies on the Languages and the Verbal Behavior of the Pennsylvania Germans II, edited by Werner Enninger, Joachim Raith, and Karl-Heinz Wandt. Stuttgart: Franz Steiner Verlag Wiesbaden GMBH.

Huntington, Gertrude Enders. 1981. "The Amish Family." Pp. 367-99 in Ethnic Families in America, edited by Charles H. Mindel, Robert W. Habenstein, and Roosevelt Jr. Wright. New York: Elsevier.

Huntington, Gertrude Enders. 1984. "Cultural Interaction during Time of Crisis: Boundary Maintenance and Amish Boundary Definition." Pp. 92-118 in Internal and External Perspectives on Amish and Mennonite Life 1, edited by Werner Enninger. Essen, West Germany: Unipress.

Huntington, Gertrude Enders. 1993. "Ideology, History, and Agriculture: Examples from Contemporary North America." Culture and Agriculture 45/46(Winter/Spring):21-25.

Hurst, Charles E., and David L. McConnell. 2010. An Amish Paradox: Diversity and Change in the World's Largest Amish Community Baltimore: The Johns Hopkins University Press.

Janzen, Rod. 1999. The Prairie People: Forgotten Anabaptists. Hanover, NH: University Press of New England. 


\section{Who Are the Plain Anabaptists? What Are the Plain Anabaptists? -- Anderson}

Janzen, Rod. 2005. "The Hutterites and the Bruderhof: The Relationship between an Old Order Religious Society and a 20th Century Communal Group." Mennonite Quarterly Review 79(4):505-44.

Janzen, Rod, and Max Stanton. 2010. The Hutterites in North America. Baltimore: Johns Hopkins University Press.

Johnson-Weiner, Karen M. 1998. "Community Identity and Language Change in North American Anabaptist Communities." Journal of Sociolinguistics 2(3):375-94.

Kent, Robert B., and Randall J. Neugebauer. 1990. "Research Note: Identification of Ethnic Settlement Regions: Amish-Mennonites in Ohio." Rural Sociology 55(3):425-41.

Klassen, Peter J. 2009. Mennonites in Early Modern Poland and Prussia. Baltimore: Johns Hopkins University Press.

Klassen, Walter. 2001. Anabaptism: Neither Catholic nor Protestant. Kitchner, ON: Pandora Press.

Kline, Edward A., and Monroe L. Beachy. 1998. "History and Dynamics of the New Order Amish of Holmes County, Ohio." Old Order Notes (18):7-19.

Klopfenstein, Perry A. 2008. Marching to Zion: A History of the Apostolic Christian Church of America: The Apostolic Christian Church of America.

Knight, James A. 1980. "The Old Order Amish: Lessons from Kansas Ethnography." Plains Anthropologist 25(89):229-33.

Kniss, Fred. 1996. "Ideas and Symbols as Resources in Intrareligious Conflict: The Case of American Mennonites." Sociology of Religion 57(1):7-23.

Kraybill, Donald. 1987. "At the Crossroads of Modernity: Amish, Mennonites, and Brethren in Lancaster County in 1880." Pennsylvania Mennonite Heritage 10(January):2-12.

Kraybill, Donald. 1994. "Plotting Social Change across Four Affiliations." Pp. 53-74 in The Amish Struggle with Modernity, edited by Donald Kraybill and Marc Olshan. Hanover: University Press of New England.

Kraybill, Donald. 2003. "Negotiating with Caesar." Pp. 3-21 in The Amish and the State, edited by Donald Kraybill. Baltimore: Johns Hopkins University Press. 


\section{Journal of Amish and Plain Anabaptist Studies, Volume 1, Issue 1 (April), 2013}

Kraybill, Donald. 2004. "The Redemptive Community: An Island of Sanity and Silence." Pp. 36-55 in Writing the Amish: The Worlds of John A. Hostetler, edited by David L Weaver-Zercher. University Park, PA: Pennsylvania State University Press.

Kraybill, Donald. 2010. Concise Encyclopedia of Amish, Brethren, Hutterites, and Mennonites. Baltimore: Johns Hopkins University Press.

Kraybill, Donald, and Carl Desportes Bowman. 2001. On the Backroad to Heaven: Old Order Hutterites, Mennonites, Amish, and Brethren. Baltimore: Johns Hopkins University Press.

Lamme, Ary J. 2001. "Old Order Amish Homelands." in Homelands: A Geography of Culture and Place, edited by R.I. Nostrand and L.E. Estaville. Baltimore: Johns Hopkins University Press.

Lee, Daniel B. 2000. Old Order Mennonites: Rituals, Beliefs, and Community. Chicago: Burnham Publishers.

Loewen, Harry, Steve Nolt, Carol Duerksen, and Elwood Yoder. 1996. Through Fire \& Water: An Overview of Mennonite History. Scottdale, PA: Herald Press.

Loewen, Royden. 2008. "To the Ends of the Earth: An Introduction to the Conservative Low German Mennonites in the Americas." Mennonite Quarterly Review 82(3):427-48.

Longhofer, Jeffrey. 1993. "Household and Community: The Alexanderwohl Mennonites and Two Counterfactuals, the Amish and Hutterites." Research in Economic Anthropology 14:153-88.

Loomis, Charles P. 1960. "The Old Order Amish as a Social System." Pp. 212-48 in Social Systems: Essays on Their Persistence and Change. Princeton, NJ: D. Van Nostrand Company.

Loomis, Charles P., and Carl R. Jantzen. 1962. "Boundary Maintenance vs. Systemic Linkage in School Integration: The Case of the Amish in the United States." Journal of the Pakistan Academy for Village Development 3(2):1-25.

Louden, Mark L. 1989. "Syntactic Variation and Change in Pennsylvania German." Pp. 30-40 in Studies on the Languages and the Verbal Behavior of the Pennsylvania Germans II, edited by Werner Enninger, Joachim Raith, and Karl-Heinz Wandt. Stuttgart: Franz Steiner Verlag Wiesbaden GMBH. 


\section{Who Are the Plain Anabaptists? What Are the Plain Anabaptists? -- Anderson}

Marsden, George M. 2006. Fundamentalism and American Culture. New York: Oxford University Press.

Mommsen, Peter. 2004. Homage to a Broken Man: The Life of J. Heinrich Arnold. Rifton, NY: Plough Publishing House.

Mook, Maurice A. 1973. "The Old Order Amish of Pennsylvania." Pp. 74-93 in The Ethnic Experience in Pennsylvania, edited by John E. Bodnar. Lewisburg, PA: Bucknell University Press.

Mow, Merrill. 1989. Torches Rekindled: The Bruderhof's Struggle for Renewal: Rifton, NY: Plough Publishing House.

Nisbet, Robert. 2010 [1953]. The Quest for Community. Wilmington, DE: ISI Books.

Noble, Allen G. 1986. "Landscape of Piety / Landscape of Profit: The Amish-Mennonite and Derived Landscapes of Northeastern Ohio " The East Lakes Geographer 21:34-48.

Nolt, Steve. 1999a. "Plain People and the Refinement of America." Mennonite Historical Bulletin 60(4):1-11.

Nolt, Steve. 1999b. "A 'Two Kingdom' People in a World of Multiple Identities: Religion, Ethnicity and American Mennonites." Mennonite Quarterly Review 73:485-502.

Nolt, Steve. 2003. A History of the Amish. Intercourse, PA: Good Books.

Nolt, Steve, and Thomas J. Meyers. 2007. Plain Diversity: Amish Cultures \& Identities. Baltimore: Johns Hopkins University Press.

O'Neil, Daniel J. 1997. "Explaining the Amish." International Journal of Social Economics 24(10):1132-39.

Olshan, Marc. 1981. "Modernity, the Folk Society, and the Old Order Amish: An Alternative Interpretation." Rural Sociology 46(2):297-309.

Olshan, Marc. 1984. "Subversive Religion: Basic Ecclesial Communities and the Old Order Amish." Pp. 24-42 in Internal and External Perspectives on Amish and Mennonite Life 1, edited by Werner Enninger. Essen, West Germany: Unipress. 


\section{Journal of Amish and Plain Anabaptist Studies, Volume 1, Issue 1 (April), 2013}

Olshan, Marc. 1988. "Family Life: An Old Order Amish Wanifesto." Pp. 143-60 in The Religion and Family Connection: Social Science Perspectives. Provo, UT: Brigham Young University Religious Studies Center.

Oved, Yaacov. 1996. The Witness of the Brothers: A History of the Bruderhof. New Brunswick, NJ: Transaction Publishers.

Oyer, John S. 1996. "Is There an Amish Theology?" Pp. 378-02 in The Amish: Origin and Characteristics, 1693-1993, edited by Lydie Hege and Christoph Wiebe. Ingersheim: Association Française d'Histoire Anabaptiste-Mennonite.

Packull, Werner C. 1995. Hutterite Beginnings: Communitarian Experiments during the Reformation. Baltimore: Johns Hopkins University Press.

Peters, Victor. 1965. All Things Common: The Hutterian Way of Life. Minneapolis: University of Minnesota Press.

Petrovich, Christopher. 2013. "Realignment and Division in the Amish Community of Allen County, Indiana: A Historical Narrative." Journal of Amish and Plain Anabaptist Studies 1(1).

Place, Elizabeth. 2003. "Significant Legal Cases." Pp. 277-87 in The Amish and the State, edited by Donald Kraybill. Baltimore: Johns Hopkins University Press.

Plasil, Tanja, and Carel Roessingh. 2009. "The Mennonite Road to Belize." Pp. 43-71 in Between Horse \& Buggy and Four-Wheel Drive: Change and Diversity among Mennonite Settlements in Belize, Central America, edited by Carel Roessingh and Tanja Plasil. Amsterdam: VU University Press.

Pratt, Dorothy O. 2004. Shipshewana: An Indiana Amish Community. Bloomington: Indiana University Press.

Pride, Richard A. 2003. "Elmo Stoll and the Christian Community at Cookeville." Border States: Journal of the Kentucky-Tennessee American Studies Association (14):3649.

Raith, Joachim. 1980. "Types of Speech Communities and Language Use." Pp. 131-46 in Understanding Bilingualism, edited by Werner Hüllen. Frankfurt, Germany: Peter Lang.

Redekop, Calvin. 1977. "The Plain People: An Interpretation." Mennonite Quarterly Review 51(4):266-77. 


\section{Who Are the Plain Anabaptists? What Are the Plain Anabaptists? -- Anderson}

Redekop, Calvin W. 1989. Leaving Anabaptism: From Evangelical Mennonite Brethren to Fellowship of Evangelical Bible Churches. Telford, PA: Pandora Press.

Redekop, Calvin, and John A. Hostetler. 1964. "Education and Boundary Maintenance in Three Ethnic Groups." Review of Religious Research 5(2):80-91.

Redfield, Robert. 1947. "The Folk Society." American Journal of Sociology 52(January):293-308.

Roessingh, Carel. 2007. "Mennonite Communities in Belize." International Journal of Business and Globalisation 1(1):107-24.

Rubin, Julius. 2000. The Other Side of Joy: Religious Melancholy among the Bruderhof. New York: Oxford University Press.

Rumsey, Suzanna Kesler. 2010. "Faith in Action: Heritage Literacy as a Synchronisation of Belief, Word, and Deed." Literacy 44(3):137-43.

Sawatzky, Tamara A. 2005. "The Dutch Windmill as an Icon of Russian Mennonite Heritage." Mennonite Quarterly Review 79(2):191-206.

Scott, Stephen. 1988. The Amish Wedding and Other Special Occasions of the Old Order Communities. Intercourse, PA: Good Books.

Scott, Stephen. 1996. An Introduction to Old Order and Conservative Mennonite Groups. Intercourse, PA: Good Books.

Scott, Stephen. 1997. Why Do They Dress That Way? Intercourse, PA: Good Books.

Scott, Stephen. 2001. Amish Houses \& Barns. Intercourse, PA: Good Books.

Scott, Stephen, and Kenneth Pellman. 1999. Living without Electricity. Intercourse, PA: Good Books.

Smucker, Melvin R. 1988. "How Amish Children View Themselves and Their Families: The Effectiveness of Amish Socialization." Brethren Life and Thought 33(Summer):218-36.

Snyder, C. Arnold. 1995. Anabaptist History and Theology. Kitchner, ON: Pandora Press.

Stark, Rodney, and William Sims Bainbridge. 1979. "Of Churches, Sects, and Cults: Preliminary Concepts for a Theory of Religious Movements." Journal for the Scientific Study of Religion 18(2):117-33. 


\section{Journal of Amish and Plain Anabaptist Studies, Volume 1, Issue 1 (April), 2013}

Stoltzfus, Victor. 1977. "Reward and Sanction: The Adaptive Continuity of Amish Life." Mennonite Quarterly Review 51(4):308-18.

Testa, Randy-Michael. 1992. After the Fire, The Destruction of the Lancaster County Amish. Hanover, NH: University Press of New England.

Toews, Paul. 1983. "Fundamentalist Conflict in Mennonite colleges: A Response to Cultural Transition?" Mennonite Quarterly Review 57(3):241-56.

Troeltsch, Ernst. 1931 [1911]. The Social Teaching of the Christian Churches. New York: Macmillan.

Trollinger, Susan. 2012. Selling the Amish: The Tourism of Nostalgia. Baltimore: Johns Hopkins University Press.

Van Kampen, Marianne. 2009. "Beachy Amish Mennonites- Organizing Mission Work in Belize." Pp. 171-97 in Between Horse \& Buggy and Four-Wheel Drive: Change and Diversity among Mennonite Settlements in Belize, Central America, edited by Carel Roessingh and Tanja Plasil. Amsterdam: VU University Press.

Waldrep, G.C. 2008. "The New Order Amish and Para-Amish Groups: Spiritual Renewal within Tradition." Mennonite Quarterly Review 82(3):395-426.

Wandt, Karl-Heinz. 1988. "Pennsylvania German under the Influence of Modernity: Continuity vs. Discontinuity." Pp. 52-61 in Internal and External Perspectives on Amish and Mennonite Life 3, edited by Werner Enninger, Joachim Raith, and Karl-Heinz Wandt.

Waters, Mary C., and Tomás R. Jiménez. 2005. "Assessing Immigrant Assimilation: New Empirical and Theoretical Challenges." Annual Review of Sociology 31(1):10525.

Weaver-Zercher, David L. 2001. The Amish in the American Imagination. Baltimore, MD: The Johns Hopkins University Press.

Weiser, Frederick S. 1998. "The Clothing of the 'White Top' Amish of Central Pennsylvania." Pennsylvania Mennonite Heritage 21(3):2-10.

Whitehouse, Harvey. 2004. Modes of Religiosity: A Cognitive Theory of Religious Transmission. Walnut Creek, CA: AltaMira Press.

Wittmer, Joe. 1971. "Cultural Violence and Twentieth Century Progress." Practical Anthropology 18:146-55. 
Who Are the Plain Anabaptists? What Are the Plain Anabaptists? -- Anderson

Yoder, Paton. 1991. Tradition \& Transition: Amish Mennonites and Old Order Amish, 1800-1900. Scottdale, PA: Herald Press.

Zablocki, Benjamin. 1971. The Joyful Community: An Account of the Bruderhof, a Communal Movement Now in Its Third Generation. Baltimore: Penguin Books. 


\title{
Appendix A: Conservative and Old Order Plain Anabaptist Groups in Canada and the U.S.
}

\author{
Mennonites (Swiss) ${ }^{*}$ \\ Conservative: Group A \\ Biblical Mennonite Alliance \\ Keystone Mennonite Fellowship \\ South Atlantic Mennonite Conference \\ Unaffiliated [Indiana-Michigan network, once known as "Sharing \\ Concerns”] \\ Unaffiliated \\ Conservative: Group B \\ Cumberland Valley Mennonite Church \\ Mid-Atlantic Mennonite Fellowship \\ Midwest Mennonite Fellowship \\ Southeastern Mennonite Conference \\ Unaffiliated \\ Conservative: Group C \\ Bethel Fellowship \\ Hope Mennonite Fellowship \\ Northeastern Mennonite Conference \\ Pilgrim Mennonite Conference \\ Western Conservative Mennonite Fellowship \\ Unaffiliated \\ Conservative: Group D \\ Nationwide Fellowship [Swiss and Russian Mennonite] \\ Conservative: Group E \\ Conservative Mennonite Church of Ontario \\ Eastern Pennsylvania Mennonite Church \\ Haven Mennonite Fellowship \\ Washington-Franklin Mennonite Conference \\ Wisler Mennonite (Ohio) \\ York-Adams Conservative Mennonite Churches \\ Unaffiliated \\ Conservative: Miscellaneous \\ “Tennessee Churches” (Altamont) \\ “Tennessee Churches” (Lynchburg) \\ Unaffiliated [west coast network, pending organization] \\ Unaffiliated \\ Old Order: Automobile groups \\ Markham-Waterloo Mennonite Conference \\ Reformed Mennonite \\ Weaverland Mennonite Conference (Horning) \\ Wisler Mennonite (Ohio-Indiana)
}


Who Are the Plain Anabaptists? What Are the Plain Anabaptists? -- Anderson

Old Order: Horse \& buggy groups

Groffdale Mennonite Conference (Wenger)

Old Order Mennonite, David Martin group

Old Order Mennonite (Ontario)

Old Order Mennonite (Virginia) [three subgroups]

Orthodox Mennonite

Reidenbach Mennonite [subgroups number in the mid-teens]

Stauffer Mennonite

Unaffiliated

\section{Mennonites (Russian / Low German)}

Church of God in Christ, Mennonite (Holdeman) [Swiss and Russian Mennonite]

Kleine Gemeinde

Old Colony Mennonites [various subgroups]

Reinländ Mennononites [Manitoba and Ontario subgroups]

Sommerfeld Mennonites [conservative and Old Order-oriented subgroups]

\section{Hutterites}

Dariusleut Hutterites

Lehrerleut Hutterites

Schmiedeleut Group 1 Hutterites

Schmiedeleut Group 2 Hutterites

Unaffiliated (Elmendorf)

\section{Amish}

Old Order Amish

Byler Amish

Dan Amish (Andy Weaver)

"Michigan churches"

Nebraska Amish [three groups]

New Order Amish [undifferentiated]

Old Order Amish [undifferentiated]

Swartzentruber Amish [at least three groups]

Swiss Amish [undifferentiated]

Troyer Amish

Unaffiliated [small, autonomous groups]

Amish-Mennonites

Ambassadors Amish-Mennonite

Beachy Amish-Mennonite

Berea Amish-Mennonite

“Car Amish” (Spring Garden-type)

Maranatha Amish-Mennonite

Mennonite Christian Fellowship

Midwest Beachy Amish-Mennonite 
Journal of Amish and Plain Anabaptist Studies, Volume 1, Issue 1 (April), 2013

Tampico Amish-Mennonite

Unaffiliated

\section{Brethren}

Brethren, horse \& buggy [undifferentiated]

Dunkard Brethren

German Baptist Brethren

Old Brethren

Old German Baptist Brethren

Old German Baptist Brethren (New Conference)

Unaffiliated conservative Brethren [Pennsylvania-based network]

\section{Apostolic Christian Church}

Apostolic Christian Church (Nazarean)

Apostolic Christian Church of America

Apostolic Christian Faith

Christian Apostolic Church

German Apostolic Christian Church

Nazarene Christian Congregation

Undifferentiated congregations solely in Europe

\section{Bruderhof}

Bruderhof (Church Communities International)

\section{Miscellaneous}

Charity churches (Charity Ministries / Ephrata Ministries)

Unassociated Charity-type churches

Lobelville, Tennessee-type churches

Scottsville, Kentucky-type churches

Unaffiliated (horse \& buggy) [including off-shoots of Elmo Stoll's Christian

Community]

Unaffiliated (automobile) [largely fringe-plain churches that reject categorization]

*Group categories somewhat follows those of Scott (1996). 